ISSN (print): 2706- 6908, ISSN (online): 2706-6894

Vol.15 No.1 Mar 2020

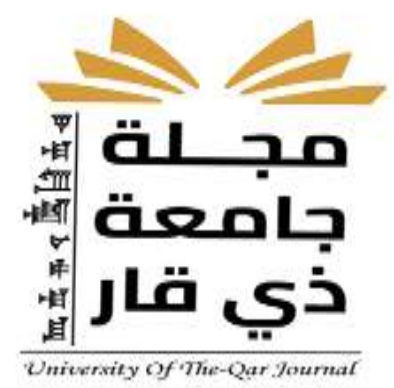

\title{
SAFETY AND EFFECTIVENESS OF RIBOON-LIKE WIND TURBINE
}

\author{
Josef B. FLIZIKOWSKI ${ }^{1}$, Raid Salman Fahad ${ }^{2}$, Ali AL-ZUBIEDY ${ }^{3}$, \\ ${ }^{1}$ University of Science and Technology in Bydgoszcz, Faculty of Mechanical Engineering, \\ raidalfahad@gmail.com \\ ${ }^{2}$ Mustansiriyah University, College of Engineering, Mechanical Engineering Department \\ ${ }^{3}$ University of Babylon, Faculty of Materials Engineering. \\ https://doi.org/10.32792/utq/utj/vol15/1/4
}

\begin{abstract}
Designing an innovative, ribbon-like wind turbine, a devices to convert wind energy into electricity, requires analysis, simulations and calculations of strength and usefulness characteristics. Such analysis may be carried out on the basis of existing numerical methods. Developed models of the pressure, forces, power and torqu, when converting wind energy with variable speed, for the fundamental innovation.

A conceptual design was realized and fundamental numerical strength tests and power of a wind power plant with a turbine which has ribbon blades. Wind turbine with ribbon blades was subjected to safety analysis: strength and efficiency.

The obtained results allow to determine the theoretical strength of individual arms of rotor with their maximum displacement. All the results allowed to determine the distribution of the safety factor on the rotor structure, which in theory allows predicting durability during use. The theoretical analysis determined the powers depending from the wind speed, efficiency of the working rotor. Also carried out the elementary analysis of the effectiveness of the existing, new idea, construction of wind power plant with a turbine which has ribbon blades
\end{abstract}

Keywords: design, innovative wind turbine

\section{Introduction}

Many ideas are known, design solutions, ways of operating wind power, descriptions of power quality and energy [Baranowski, 2014, Boczar, 2010, Burton 2001, Flizikowski 2014, 2016, 2017, Szarek, 2018, and Zmarzły, 2014], operational efficiency [Czyż, 2017, Flaga 2008, Lubośny, 2010, and Maroński, 2016] and the harmlessness of their effect on the environment [Malczyk, 2013, Matyka, 2013, Wolańczyk, 2009, others in the bibliography list]. Turbine with ribbon wing is an innovative solution developed on Faculty of Mechanical Engineering, University of Science and Technology in Bydgoszcz, Poland, [Flizikowski and team, 2016]. In this paper an attempt was test to 


\section{University of Thi-Qar Journal}

ISSN (print): 2706- 6908, ISSN (online): 2706-6894

Vol.15 No.1 Mar 2020

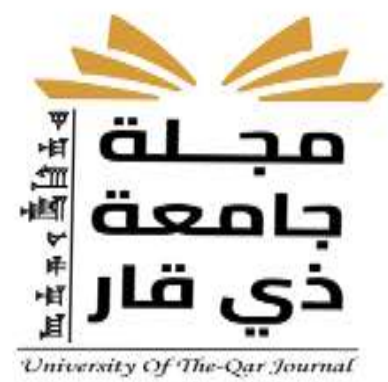

determine the theoretical and practical strength and utility characteristics, including turbine efficiency with ribbon wings.

The task can be divided into two stages. The first is the computational part leading to the determination of the theoretical power of the turbine. The second is to determine the strength of critical turbine points.

The main aim is to support conceptual design, digital testing of the strength of selected the elements profiles and power at the output of a wind power with a new turbine with ribbon wings. In addition, conducting an elementary analysis of its effectiveness.

Achieving the aim will help solve the problem formulated in the form of a question:

what is the influence of the new idea of wind energy conversion, construction, profile and the form of turbine with ribbon wings for safety and efficiency of its work.

\section{The essence of an innovative solution}

The essence of a conceptual turbine solution with ribbon wings, there is a rotating rotor (impeller) with horizontal axis of rotation (fig.1) with arranged radially ribbon wings same the form eight-number (8), cross mounted, creating four loops of rotor blades dislocated from each other by an angle $90^{\circ}$. It is characterized that the system functional, processing, converting energy, creates with other elements: hub, gear (transmission), generator, tower and servo-mechanism - wind power plant for electricity production.

a)

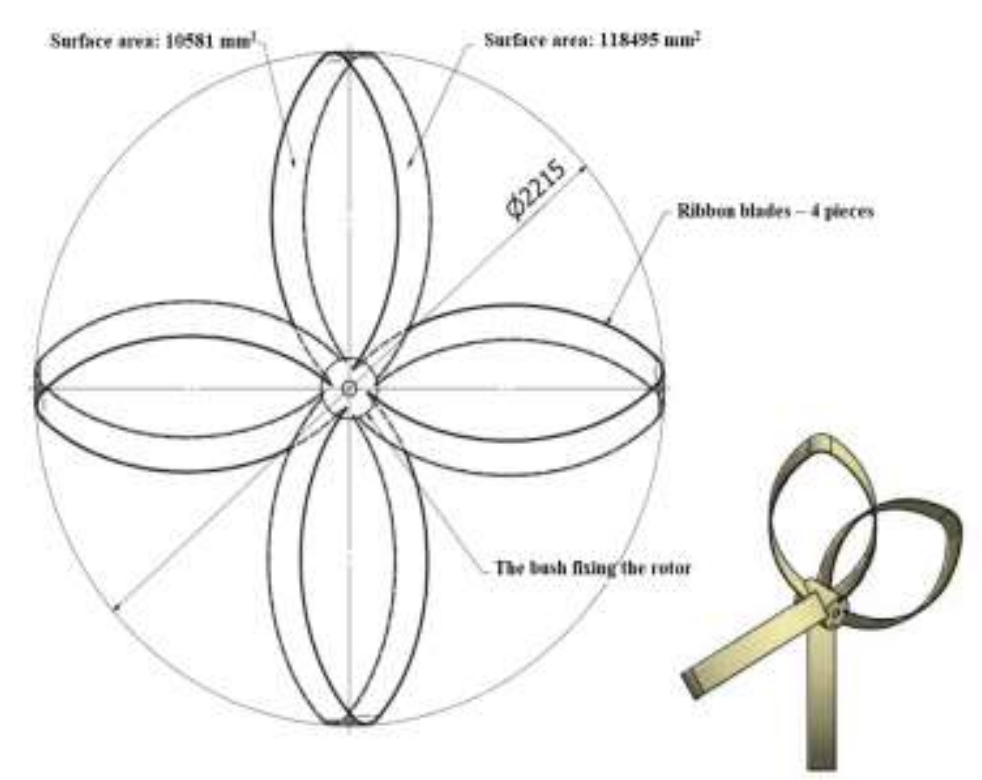

b)

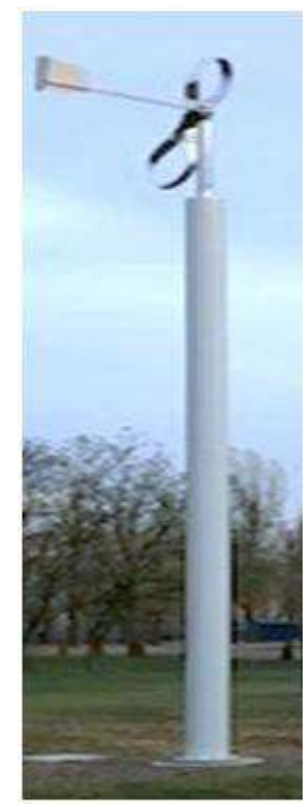

Fig. 1. Structural sketch of the rotor with dimensions (a) and a real wind farm with a ribbon turbine (b) [Source: own materials]

Ribbon is a two-dimensional compact topological variety existing in three-dimensional space, which can be obtained by bonding, at the end of the construction material for ribbon wings such as 


\section{University of Thi-Qar Journal}

ISSN (print): 2706- 6908, ISSN (online): 2706-6894

Vol.15 No.1 Mar 2020

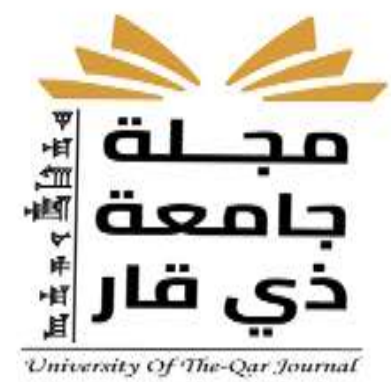

aluminum, in order to a double loop in the form eight-number (8), it created two external and internal pages. A ribbon wing was created it has the possibility of spatial shaping so, that in the middle of the longitudinal symmetry and in the middle of its circumference a mounting point is created in the center hub of the turbine, in addition, a control space is created, adjustment and functional compensation (working, coupled with wind speed) its geometrical form by smooth regulation of the clashes angle forming individual loops in the hub. Location and shape of the rotor ribbon wings (cross, in the shape of the form eight-number (8)), calls (produce): high torque, a multiple of radially embedded rotor ribbon wings with a smoothly changing angle of their shape, minimizes rotor movement resistance.

The ribbon shape of the working surface the rotor wings additionally increases the load-bearing effect, reduces face resistance, contributing to more efficient operation and increasing the efficiency of the all device. Rotary wind turbine rotor through shaped, embedded radially, ribbon wings turbine converts the stream kinetic energy wind movement (air) to the mechanical kinetic energy of the rotary motion of the drive shaft.

Rotary motion is used to drive an electricity generator, through a kinematic system with an increase gear (transmission). The construction of a wind turbine includes a small number of components. Slow (Low-speed) rotor and body (gondola) of the housing of fast-rotating devices, inside it, mechanisms (gear, shaft and generator) protect befor the destruction of living organisms: birds, bats, insects and others. The construction of the device can be additionally equipped with a grat protecting the rotor. The stabilization of the power plant is obtained by foundation and strength of the tubular tower (conical).

\section{Strength and usability of the solution}

The construction of the turbine allows to work with the wind directed to the rotor at different angles. However, analysing of the strength and efficiency will be subjected to wind work along the axis of rotation the rotor. Using the standard PN-EN 1991-1-4:2008, we can determine the wind speed pressure from the following formula

$$
\mathrm{q}_{\mathrm{k}}=\frac{\rho \cdot \mathrm{v}_{\mathrm{k}}^{2}}{2} \mathrm{q}_{\mathrm{k}}=\frac{\rho \cdot \mathrm{v}_{\mathrm{k}}^{2}}{2}
$$

where:

$\mathrm{qk}$ - wind speed pressure, $\mathrm{Pa}$,

$\mathrm{V}_{\mathrm{k}}^{2} \mathrm{~V}_{\mathrm{k}}^{2}$ - wind speed in a given climate zone, $\mathrm{m} \cdot \mathrm{s}^{-1}$,

$\rho$ - air density, $1,23 \mathrm{~kg} \cdot \mathrm{m}^{-3}$.

After calculating the wind speed pressure

we can calculate the characteristic load caused by the influence

of the wind from the following formula: 


\section{University of Thi-Qar Journal}

ISSN (print): 2706- 6908, ISSN (online): 2706-6894

Vol.15 No.1 Mar 2020

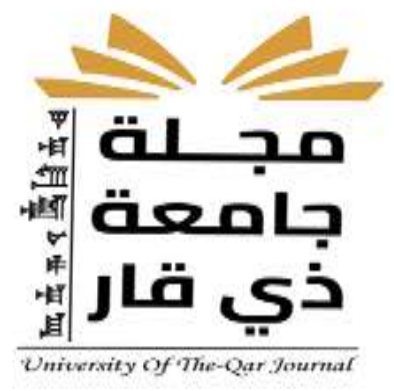

$$
\mathrm{p}_{\mathrm{k}}=\mathrm{q}_{\mathrm{k}} \cdot \beta \mathrm{p}_{\mathrm{k}}=\mathrm{q}_{\mathrm{k}} \cdot \beta_{[\mathrm{Pa}]}
$$

where:

$\mathrm{pk}$ - characteristic load caused by the influence of the wind, $\mathrm{Pa}$,

$\beta$ - coefficient actions of wind gusts, -,

The computation load used in determining the limit states of the load-capacity of the structure is determined by the formula:

$$
\mathrm{p}=\mathrm{p}_{\mathrm{k}} \cdot \gamma_{\mathrm{f}} \mathrm{p}=\mathrm{p}_{\mathrm{k}} \cdot \gamma_{\mathrm{f}}[\mathrm{Pa}]
$$

where:

$\mathrm{pk}$ - characteristic load caused by the influence of the wind, $\mathrm{Pa}$,

$\gamma \mathrm{f}$ - load coefficient, - .

After determining the computational load load and the surface area determined from the ribbon-rotor, we can calculate the apply a force to the surface under consideration. The calculated force will be directed perpendicular to the surface of the calculation. This force can be calculated from the following formula:

$$
P_{w}=p / A_{j} P_{w}=p / A_{j}[N]
$$

where:

$\mathrm{Pw}$ - unitary the resultant force perpendicular to the surface, $\mathrm{N}$,

$\mathrm{p}$ - calculation load, $\mathrm{Pa}$,

$\mathrm{Aj}$ - unitary surface area of a part of the ribbon-rotor, $\mathrm{m}^{2}$.

Knowing the resultant force on the unitary area of the airfoil, we can calculate the circumferential force $\left.\left({ }^{\mathrm{P}_{\mathrm{B}}}\right) \mathrm{P}_{\mathrm{OB}}\right)$ needed to determine the turbine power. For this target was used the following formula:

$$
\mathrm{P}_{\mathrm{OB}}=\cos \alpha \cdot \mathrm{P}_{\mathrm{w}} \mathrm{P}_{\mathrm{OB}}=\cos \alpha \cdot \mathrm{P}_{\mathrm{w}}{ }_{[\mathrm{N}]}
$$

where:

$\alpha$ - angle between Pw force yet the front plane of rotor, ${ }^{\circ}$, $\mathrm{Pw}$ - unitary resultant force on the rotor, $\mathrm{N}$.

Power of rotor for different rotational speeds, based on the variation in wind speed. The rotor speed is determined first:

$$
\mathrm{n}_{\mathrm{t}}=\frac{60 \cdot \mathrm{v}_{\mathrm{n}} \cdot \delta}{\pi \cdot \mathrm{D}} \mathrm{n}_{\mathrm{t}}=\frac{60 \cdot \mathrm{v}_{\mathrm{n}} \cdot \delta}{\pi \cdot \mathrm{D}}\left[\mathrm{min}^{-1}\right]
$$

where:

$\mathrm{Vn}$ - wind speed, $\mathrm{m} \cdot \mathrm{s}^{-1}$, 


\section{University of Thi-Qar Journal}

ISSN (print): 2706- 6908, ISSN (online): 2706-6894

Vol.15 No.1 Mar 2020

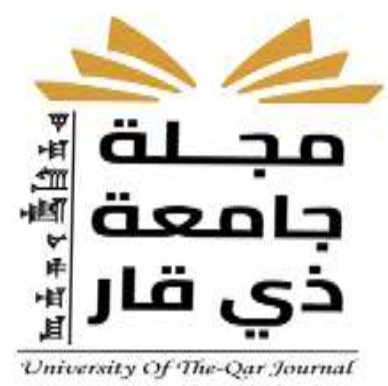

$\delta$ - discriminant of speed indicator, -,

$\mathrm{D}$ - diameter of the rotor, $\mathrm{mm}$.

Then - the theoretical power of the rotor:

$$
\mathrm{N}_{\mathrm{T}}=\frac{\sum_{\mathrm{i}} \mathrm{P}_{\mathrm{OBi}} \cdot \mathrm{R} \cdot \mathrm{n}_{\mathrm{ti}}}{9550} \mathrm{~N}_{\mathrm{T}}=\frac{\sum_{\mathrm{i}} \mathrm{P}_{\mathrm{OBi}} \cdot \mathrm{R} \cdot \mathrm{n}_{\mathrm{ti}}}{9550}
$$

where:

$\sum_{\mathrm{i}} \mathrm{P}_{\mathrm{OBi}} \sum_{\mathrm{i}} \mathrm{P}_{\mathrm{OBi}}$ - the sum of circumferential forces occurring at individual planes of the rotor, $\mathrm{N}$, $\mathrm{R}$ - $\quad$ active radius of the rotor, $\mathrm{mm}$,

$\mathrm{n}_{\mathrm{ti}}-$ given rotation speed of rotor, $\mathrm{min}^{-1}$.

Simulation using the finite element method was carried by using Autodesk Inventor software 2016vs. fig. 2. shows the place and direction of applying forces on the surfaces of rotor during load simulation.

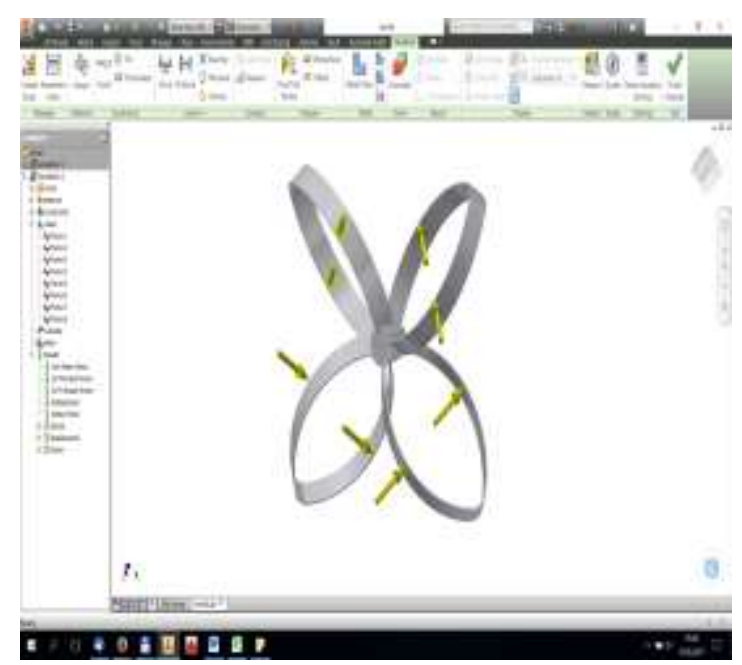

Fig. 2. Rotor load model with ribbon wings [Source: own materials]

Visible forces used for simulation were accepted as $\mathrm{P}_{\mathrm{OB}}$. There are two size in the calculation and they depend on the surface area (fig. 1). The whole has been immobilized in the axis of rotation yet, the load created in this place is entirely transferred on the foundation of the turbine. This fact is not part of the analysis. Tabela 1 presents individual values of applied forces.

Tabela 1. Arrangement of the values the forces and surface areas for critical speed [Source: own materials]

\begin{tabular}{|c|c|c|c|c|}
\hline No. & $\begin{array}{c}\text { surface areas } \\
\mathbf{A}\left[\mathbf{m}^{2}\right]\end{array}$ & $\begin{array}{c}\text { Speed } \\
\mathbf{V}_{\mathbf{K}}[\mathbf{m} / \mathbf{s}]\end{array}$ & $\begin{array}{c}\text { The resultant } \\
\text { force } \\
\mathbf{P}_{\mathbf{w}}[\mathbf{N}]\end{array}$ & $\begin{array}{c}\text { Peripheral force } \\
\mathbf{P}_{\text {OB }}[\mathbf{N}]\end{array}$ \\
\hline 1 & 0,105481 & 47 & 335 & 237 \\
\hline
\end{tabular}




\section{University of Thi-Qar Journal}

ISSN (print): 2706- 6908, ISSN (online): 2706-6894

Vol.15 No.1 Mar 2020

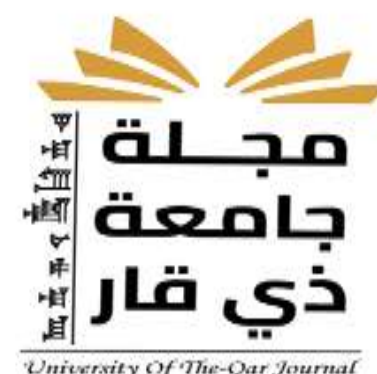

\begin{tabular}{|l|l|l|l|l|}
\hline 2 & 0,118495 & & 377 & 266 \\
\hline
\end{tabular}

Tabela 2. Material properties AW-EN 6061-T6 [Source:http://www.sebros.eu/aluminium/aluminium-EN-AW-6061ISO:-AlMg1SiCu-EN:-AW-AlMg1SiCu-PN:-PA-45-DIN:-AlMg1SiCu-wnr:-3.3211/]

\begin{tabular}{|c|c|c|c|c|c|}
\hline \multicolumn{2}{|c|}{$\begin{array}{l}\text { Alloy - condition } \\
6061 \text { T6 }\end{array}$} & \multicolumn{2}{|c|}{$\begin{array}{c}\text { Round rods } \\
\text { - diameter range } \\
\mathbf{0 ~ - ~} \mathbf{2 0 0}[\mathbf{m m}]\end{array}$} & \multicolumn{2}{|c|}{$\begin{array}{c}\text { Square rods } \\
\text { and rectangular } \\
\text { - thickness range } \\
\mathbf{0 - 2 0 0}[\mathbf{m m}]\end{array}$} \\
\hline $\begin{array}{c}\text { Tensile } \\
\text { strength Rm } \\
\text { min. } \\
\mathbf{2 6 0}[\mathbf{M P a}]\end{array}$ & $\begin{array}{l}\text { Tensile } \\
\text { strength } \\
\text { Rm max. } \\
\text { - [MPa] }\end{array}$ & $\begin{array}{l}\text { The limit of } \\
\text { plasticity } \\
\mathrm{Rp}_{02} \text { min. } \\
\mathbf{2 4 0} \text { [MPa] }\end{array}$ & $\begin{array}{l}\text { The limit of } \\
\text { plasticity } \\
\mathrm{Rp}_{02} \max . \\
\text { - }[\mathbf{M P a}]\end{array}$ & $\begin{array}{c}\text { Elongation } \\
\text { min. } \\
\mathrm{A}_{50 \mathrm{~mm}} \\
\mathbf{8}[\%]\end{array}$ & $\begin{array}{c}\text { Elongation } \\
\text { min } \\
\mathrm{A} \\
\mathbf{6}[\%]\end{array}$ \\
\hline
\end{tabular}

Calculated forces for speed of wind $47 \mathrm{~m} \cdot \mathrm{s}^{-1}$, they give the result of circumferential force, unit on level $237 \mathrm{~N}$ i $266 \mathrm{~N}$.

Rotor ribbons have been designed from aluminum AW-EN 6061-T6 (tab. 2), in the form of flats with dimensions $160 \times 20 \mathrm{~mm}$, set at an angle of $45^{\circ}$ to the hub. The model created to stay subjected strength simulation (fig. 3) and strength calculations (tab. 3).

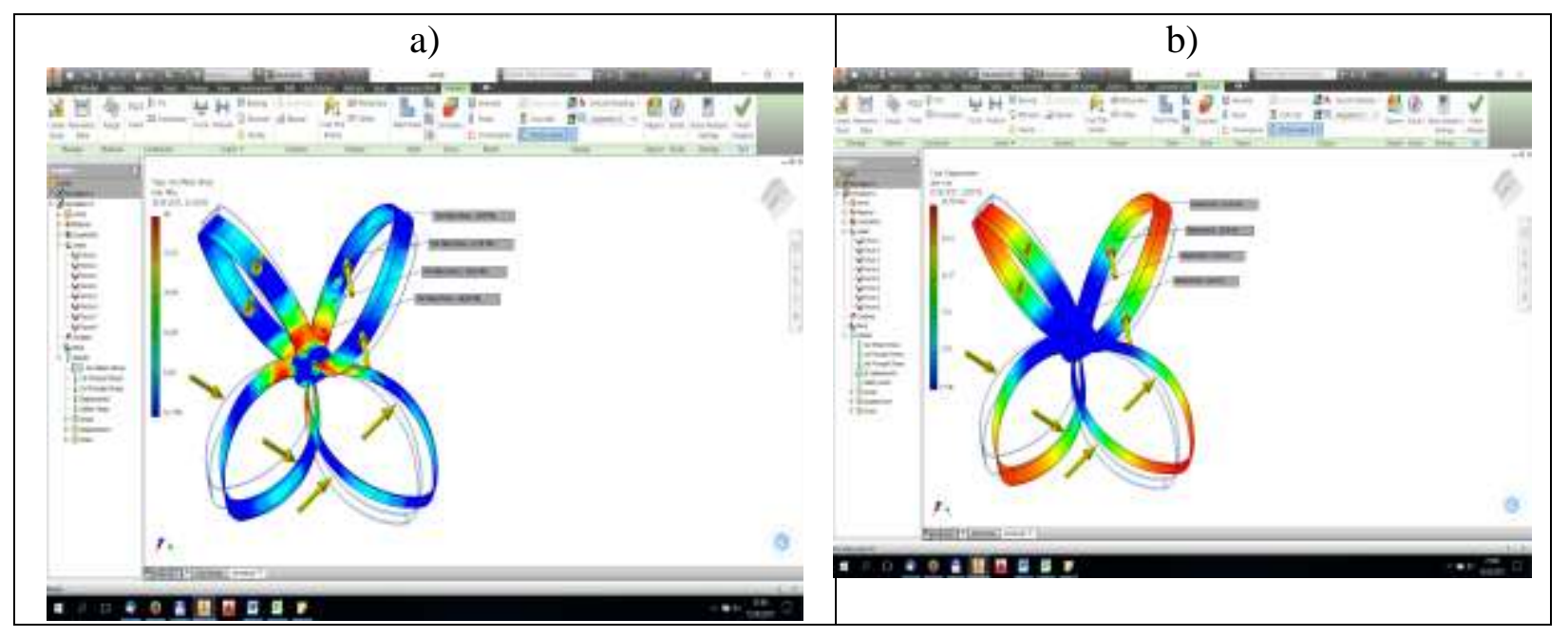


ISSN (print): 2706- 6908, ISSN (online): 2706-6894

Vol.15 No.1 Mar 2020
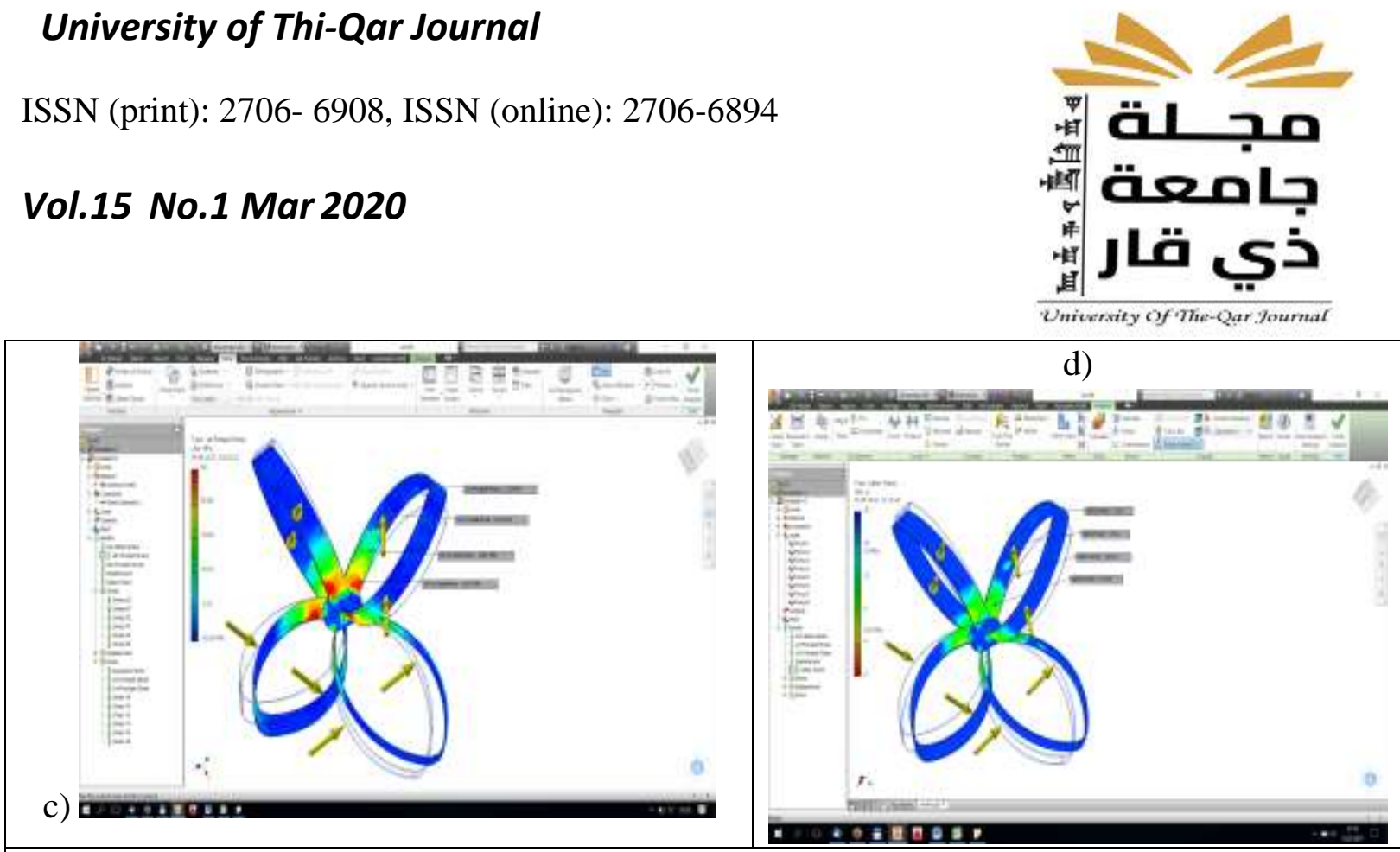

Fig. 3. Von Mises stress of a rotor-ribbon (a); Displacements of planes loaded of rotor (b); Distribution of the first main stresses on the ribbon surface (c); Distribution of the safety coefficient on the ribbon surfaces (d). [Source: own materials]

The results obtained can be concluded, that sections used in the structure are able to move the existing loads. By accepting the yield point of $240 \mathrm{MPa}$, and with the factor of safety $\mathrm{x}_{\mathrm{e}}=4$, we can determine that the acceptable stresses in the tested structure they can get value $60 \mathrm{MPa}$. In fig. 3a Von Mises stresses get a maximum value of $40 \mathrm{Mpa}$, while in fig. $3 \mathrm{c}$ the first main stresses get a maximum value of $44 \mathrm{MPa}$. These results in connection with distribution the factor of safety from fig. $3 \mathrm{~d}$ confirm the safe stability of the construction used.

Fig. $3 b$ presents the displacements occurring during the theoretical work of the rotor and can be used in the design of other wind turbine components. Anticipating the eventual deformation of the rotor, distance can be predicted, which must be designed for the correct, collision-free operation of the entire system.

Tab. 3. Loads in the crane blade or wing (wing root, fastening)

\begin{tabular}{|l|c|c|}
\hline \multicolumn{1}{|c|}{ Type of load } & Load value \\
\cline { 2 - 3 } & Fastening & Wing root \\
\hline Tension with centrifugal force, $\mathrm{P}_{\mathrm{R}}$ & $3.410 .0 \mathrm{~N}$ & $3.108 .0 \mathrm{~N}$ \\
\hline Tension in the plane, $\mathrm{Y}-\mathrm{X}: \mathrm{M}_{\mathrm{W}}+\mathrm{M}_{\dot{\mathrm{Z}}}$ & $621.1 \mathrm{Nm}$ & $308.0 \mathrm{Nm}$ \\
\hline $\begin{array}{c}\text { The moment from the wind pressure, } \\
\mathrm{M}_{\mathrm{W}(\mathrm{v}=7,2)}\end{array}$ & $234.0 \mathrm{Nm}$ & $140.4 \mathrm{Nm}$ \\
\hline $\begin{array}{c}\text { The moment from the wind pressure } \\
\mathrm{M}_{\mathrm{W}(\mathrm{v}=16)}\end{array}$ & $350.0 \mathrm{Nm}$ & $210.0 \mathrm{Nm}$ \\
\hline Gyroscopic moment, $\mathrm{M}_{\dot{\mathrm{Z}}}$ & $271.4 \mathrm{Nm}$ & $98.4 \mathrm{Nm}$ \\
\hline $\begin{array}{c}\text { Bending in the plane, } \mathrm{X}-\mathrm{Z}: \\
\mathrm{M}_{\mathrm{G}}+\mathrm{M}_{\mathrm{e}}+\mathrm{M}_{\mathrm{O}}+\mathrm{M}_{\mathrm{H}}\end{array}$ & $587.6 \mathrm{Nm}$ & $442.0 \mathrm{Nm}$ \\
\hline From the weight of a wings, $\mathrm{P}_{\mathrm{G}}, \mathrm{M}_{\mathrm{G}}$ & $210.9 \mathrm{Nm}$ & $134.0 \mathrm{Nm}$ \\
\hline
\end{tabular}




\section{University of Thi-Qar Journal}

ISSN (print): 2706- 6908, ISSN (online): 2706-6894

Vol.15 No.1 Mar 2020

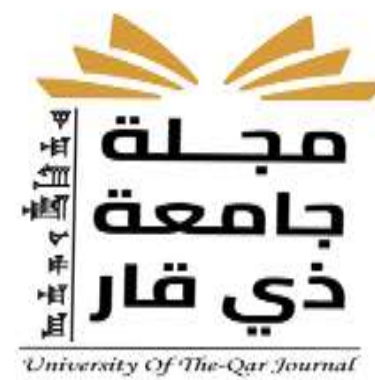

\begin{tabular}{|l|c|c|}
\hline From eccentricity, $\mathrm{P}_{\mathrm{R} 5}, \mathrm{M}_{\mathrm{e}}$ & $210.6 \mathrm{Nm}$ & $210.6 \mathrm{Nm}$ \\
\hline From the torque, $\mathrm{M}_{\mathrm{O}}$ & $102.0 \mathrm{Nm}$ & $62.0 \mathrm{Nm}$ \\
\hline From the braking torque, $\mathrm{M}_{\mathrm{H}}$ & $64.0 \mathrm{Nm}$ & $35.4 \mathrm{Nm}$ \\
\hline
\end{tabular}

Determination of the flexibility ideas, the construction of assembly and ribbon panels on the conversion of wind energy into useful work, that is, the efficiency of the rotor can be carried out by calculating the theoretical power the system and reference it to the real state.

The real state a working wind turbine (Fig. 1b), and the data for comparison with the theoretical calculations are collected during its work.

For pressure and load calculations, formulas have been used (1) - (7), variable wind velocity $\mathrm{V}_{\mathrm{K}}$ in the range $(6-47) \mathrm{m} \cdot \mathrm{s}^{-1}$. Tables 4 and 5 show the calculations about the pressure and force distribution on the surface of the ribbons.

Table 4. To set of pressure distribution and on the surface of the ribbons

\begin{tabular}{|c|c|c|c|c|c|}
\hline No. & $\begin{array}{c}\text { Surface } \\
\mathbf{a r e a} \\
\mathbf{A}\left[\mathbf{m}^{\mathbf{2}}\right]\end{array}$ & $\begin{array}{c}\text { Velocity } \\
\mathbf{V}_{\mathbf{K}}\left[\mathbf{m} \cdot \mathbf{s}^{-\mathbf{1}}\right]\end{array}$ & $\begin{array}{c}\text { Pressure of } \\
\text { wind speed } \\
\mathbf{q}_{\mathbf{k}}[\mathbf{P a}]\end{array}$ & $\begin{array}{c}\text { Characteristic } \\
\text { load } \\
\mathbf{p}_{\mathbf{k}}[\mathbf{P a}]\end{array}$ & $\begin{array}{c}\text { Calculation load } \\
\mathbf{p}[\mathbf{P a}]\end{array}$ \\
\hline 1 & 0,105481 & 6 & 22 & 40 & 52 \\
\hline 2 & 0,118495 & 12 & 89 & 159 & 207 \\
\hline 3 & 0,105481 & 18 & 199 & 359 & 466 \\
\hline 4 & 0,118495 & 24 & 354 & 638 & 1210 \\
\hline 5 & 0,105481 & $29 *$ & 517 & 931 & 1763 \\
\hline 6 & 0,118495 & 35 & 753 & 1356 & 2419 \\
\hline 7 & 0,105481 & 41 & 1034 & 1861 & 3179 \\
\hline 8 & 0,118495 & 47 & 1359 & 2445 & \\
\hline
\end{tabular}

Table 5. To set of force distribution on the surface of the ribbons and the obtained rotational speeds and power on the turbine rotor with ribbon blades [Source: own materials]

\begin{tabular}{|c|c|c|c|c|c|}
\hline No. & $\begin{array}{c}\text { The resultant } \\
\text { Velocity } \\
\mathbf{V}_{\mathbf{K}}\left[\mathbf{m}^{-1} \mathbf{s}^{-1}\right]\end{array}$ & $\begin{array}{c}\text { The } \\
\text { forcenferential } \\
\sum_{i} P_{w i} \sum_{i} P_{w i} \\
{[\mathrm{~N}]}\end{array}$ & $\begin{array}{c}\sum_{i} P_{O B i} \\
\text { force }\end{array}$ & $\begin{array}{c}\text { Circles } \\
\mathbf{n}_{\mathbf{t}}\left[\mathbf{m i n}^{-1}\right]\end{array}$ & $\begin{array}{c}\text { Theoretical } \\
\text { power } \\
\mathbf{N}_{\mathbf{T}}[\mathbf{k W}]\end{array}$ \\
\hline 1 & 6 & 46 & 33 & 21 & 0,08 \\
\hline 2 & 12 & 186 & 131 & 41 & 0,63 \\
\hline 3 & 18 & 418 & 295 & 62 & 2,13 \\
\hline 4 & 24 & 743 & 525 & 83 & 5,04 \\
\hline 5 & $29 *$ & 1084 & 767 & 100 & 8,89 \\
\hline
\end{tabular}




\section{University of Thi-Qar Journal}

ISSN (print): 2706- 6908, ISSN (online): 2706-6894

Vol.15 No.1 Mar 2020

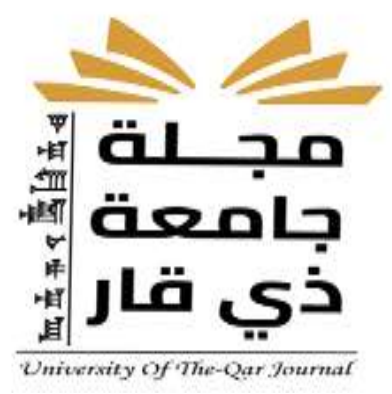

\begin{tabular}{|l|l|l|l|l|l|}
\hline 6 & 35 & 1579 & 1117 & 121 & 15,63 \\
\hline 7 & 41 & 2167 & 1533 & 141 & 25,13 \\
\hline 8 & 47 & 2848 & 2014 & 162 & 37,86 \\
\hline
\end{tabular}

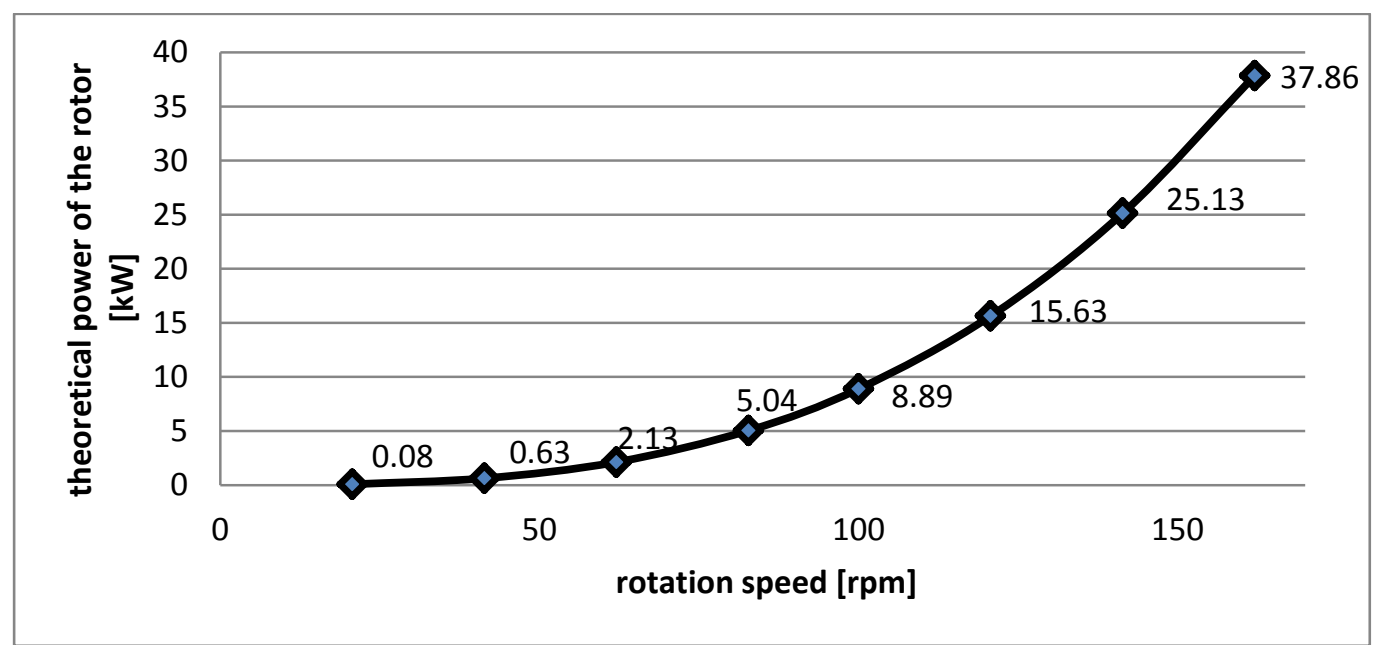

Fig. 4. Theoretical power of a ribbon turbine as a function of wind speed [Source: own materials]

The most important parameter about the usefulness of a wind turbine is power range. Fig. 4. shows to set of theoretically generated powers as a function of rotor speed.

\section{Conclusions}

A conceptual design was realized and fundamental numerical strength tests and power of a wind power plant with a turbine which has ribbon blades. Wind turbine with ribbon blades was subjected to safety analysis: strength and efficiency.

Both issues were taken in the theoretical range. The simulation was carried out using the finite element method, which allowed to determine the maximum stress, loads and safety of the structure. The obtained results allow to determine the theoretical strength of individual arms of rotor with their maximum displacement. All the results allowed to determine the distribution of the safety factor on the rotor structure, which in theory allows predicting durability during use. The theoretical analysis determined the powers depending from the wind speed, efficiency of the working rotor. Also carried out the elementary analysis of the effectiveness of the existing, new idea, construction of wind power plant with a turbine which has ribbon blades. The main aim was achieved by solution to the problem formulated in the form of a question: what is the effect of the new idea of wind energy conversion, construction, profile and the form of a wind turbine blades on the safety and efficiency of its work. A wind turbine with ribbon blades can be included to the group of turbines near the home. This solution allows to electricity production for own needs, the surplus can be discharged to the power grid while gaining economic benefits. Theoretically obtained maximum powers at the level of $\sim 30 \mathrm{~kW}$ (at a critical wind speed of $47 \mathrm{~m} \cdot \mathrm{s}^{-1}$ ) after taking into account possible losses, forming in the system, it 


\section{University of Thi-Qar Journal}

ISSN (print): 2706- 6908, ISSN (online): 2706-6894

Vol.15 No.1 Mar 2020

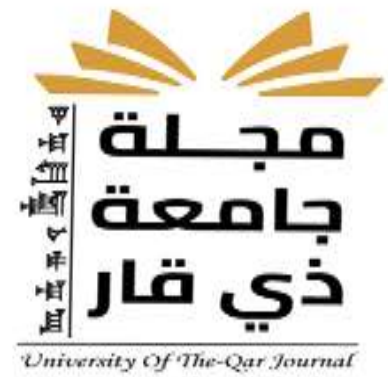

would allow to supply a small household, savings and benefits from the sale of surplus production. Assuming the maximum wind speed occurring in Poland area,

it can be tell that theoretically the construction of the rotor blades is prepared to transfer such loads. Obtained high safety factor of the rotor structure allows forecasting, that the rotor will work under difficult load conditions and a long period of time. Obtained from the theoretical simulation of displacement of the rotor ends under the influence of the loading force resulting from the wind speed and the size of the surface on the panel, allow the adoption of such a structural solution, which will enable collision-free rotation of the system. The efficiency analysis shows that already at a wind speed of $12 \mathrm{~m} \cdot \mathrm{s}^{-1}$, i.e. $43 \mathrm{~km} \cdot \mathrm{h}^{-1}$ the turbine gets a power of $0.63 \mathrm{~kW}$, with these parameters, the work of the system will be successfully implemented.

\section{Bibliografia}

[1] Al-Zubiedy A.: Rozdrabniacze wielotarczowe badania i stabilizacja produktu. Seria MONOGRAFIE nr 126, WU PC, Częstochowa 2006

[2] Baranowski A.: Farmy wiatrowe: zagrożenia dla człowieka i środowiska, Wydawnictwo Uczelniane Uniwersytetu Technologiczno-Przyrodniczego, Bydgoszcz 2014.

[3] Boczar T.: Energetyka wiatrowa. Aktualne możliwości wykorzystania (wyd. 2 zmienione), Wydawnictwo SIMP Agenda Wydawnicza, Redakcja"Pomiary Automatyka Kontrola",Warszawa 2008

[4] Boczar T.: Wykorzystanie energii wiatru, Wydawnictwo PAK, Warszawa 2010.

[5] Burton T., Sharpe D., Jenkins N., Bossanyi E.: Wind energy, handbook, John Wiley \& Sons LTD, England West Susses 2001.

[6] Czyż Z., Kamiński Z.: Badania wirnika turbiny wiatrowej o regulowanym położeniu łopat roboczych, Wydano przez Politechnika Lubelska, Wydział Mechaniczny, Katedra Termodynamiki, Mechaniki Płynów i Napędów Lotniczych, Lublin 2017

[7] Flaga A.: Inżynieria wiatrowa. Podstawy i zastosowania, Wydawnictwo Arkady, 2008

[8] Flizikowski i Zespół: Systemy wytwarzania uwzględniające nowe źródła energiii obniżanie emisji zagrożeń. Wydaw. Uczel. UTP, Bydgoszcz 2018

[9] Flizikowski J. i Zespół. Turbina wiatrowa o łopatach wstęgowych. UP RP Zgłoszenie 2016

[10] Flizikowski J. i Zespół, P.397297: Stacjonarna siłownia, elektrownia wodna z turbiną o łopatach rurowych. RP.651.23.15.11 2015-01-09

[11] Flizikowski J., P.413815. Elektrownia wiatrowa z turbiną o łopatach stożkowych./2015.09.03

[12] Flizikowski J. i Zespół, P.220459: Stacjonarna siłownia, elektrownia wodna z turbiną o łopatach rurowych. RP.651.23.15.11 2016-02-10

[13] Jagodziński W.: Silniki wiatrowe, Zakłady Graficzne im. Kasprzaka w Poznaniu, Warszawa 1959.

[14] Kieć J.: Odnawialne źródła energii, Wydawnictwo Akademii Rolniczej, Kraków 2007.

[15] Lubośny Z.: Elektrownie wiatrowe $w$ systemie elektroenergetycznym, Wydawnictwo NaukowoTechniczne, Warszawa 2007.

[16] Malczyk T.: Antropopresja ekoenergetyczna w procesie zmiany krajobrazu na przyktadzie wybranych farm wiatrowych w Polsce, Wydawnictwo Uniwersytetu Przyrodniczego we Wrocławiu, Wrocław 2013.

[17] Maroński R.: Siłownie wiatrowe, Oficyna Wydawnicza Politechniki Warszawskiej, Warszawa 2016.

[18] Matyka M., Kołodziej B.: Odnawialne źródła energii. Rolnicze surowce energetyczne, Wydawnictwo Powszechne Wydawnictwo Rolnicze i Leśnie, Poznań 2013.

[19] Mężyk A., Jureczko M.: Optymalizacja wielokryterialna łopat elektrowni wiatrowej ze względu na minimalizację drgań, Wydawnictwo Politechniki Śląskiej, Gliwice 2006. 


\section{University of Thi-Qar Journal}

ISSN (print): 2706- 6908, ISSN (online): 2706-6894

Vol.15 No.1 Mar 2020

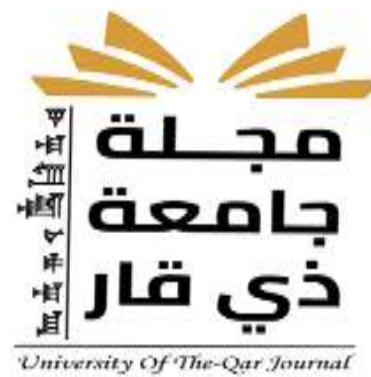

[20] Szarek M.: Projekt i badania elektrowni wiatrowej z turbiną o łopatach wstęgowych. Prace WIM UTP, Bydgoszcz 2018

[21] Szumanowska M., Szumanowski A.: Fotoogniwa i turbiny wiatrowe w systemach energetycznych, Oficyna Wydawnicza Politechniki Warszawskiej, Warszawa 1997.

[22] Wolańczyk F.: Elektrownie wiatrowe, Wydawnictwo i Handel Książkami „KaBe”, Krosno 2009.

[23] Zmarzył D.: Badania jakości energii w wybranej farmie wiatrowej, Politechnika Opolska Oficyna Wydawnicza, Opole 2014.

[24] Wind Energy Solution, https://windenergysolutions.nl/ [Dostęp 12.04.2017]

[25] Wind Power, http://www.windpowermonthly.com/ [Dostęp 04.04.2017]

[26] Wind Energy Barometers, https://www.eurobserv-er.org/ [Dostęp 05.05.2017]. 